九州大学学術情報リポジトリ

Kyushu University Institutional Repository

\title{
Analysis of Characteristics and Efficiency of Smart Locker System (Case Study: Jabodetabek)
}

Refaningati, Tuesta

Civil Engineering Department, Faculty of Engineering, Universitas Indonesia

Nahry

Civil Engineering Department, Faculty of Engineering, Universitas Indonesia

Tangkudung, S. W. , Ellen

Civil Engineering Department, Faculty of Engineering, Universitas Indonesia

Kusuma, Andyka

Civil Engineering Department, Faculty of Engineering, Universitas Indonesia

https://doi.org/10.5109/2740966

出版情報：Evergreen. 7 (1)，pp.111-117，2020-03. 九州大学グリーンテクノロジー研究教育センター バージョン：

権利関係 : 


\title{
Analysis of Characteristics and Efficiency of Smart Locker System (Case Study: Jabodetabek)
}

\author{
Tuesta Refaningati ${ }^{1, *}$, Nahry ${ }^{1}$, Ellen S.W. Tangkudung ${ }^{1}$, Andyka Kusuma ${ }^{1}$ \\ ${ }^{1}$ Civil Engineering Department, Faculty of Engineering, Universitas Indonesia \\ E-mail: tuestarefaningati@gmail.com
}

(Received October 31, 2019; Revised January 23, 2020; accepted February 24, 2020).

\begin{abstract}
Last mile delivery is the last trip of an item before it arrives at the final destination. The current increase of last mile delivery is the impact of increasing home delivery services in areas that see a growing development of e-commerce. There are several issues in the operational process, including the high number of trips taken from parcel delivery service. One of the innovations used to solve these issues is the smart locker system. The objective of this research is to analyze the characteristics and efficiency of the smart locker system that has been running in Jabodetabek to reduce the trips taken for home delivery service. Data analysis was performed using the travel diary data of a single smart locker operator. Results showed that the use of smart locker is not without faults and causes the performance of each transit hub (as a part of a trip chain of smart lockers) to significantly differ. One issue includes the variable of waiting time either at the pickup or at the delivery of shipments. Another issue is that the coverage area for each locker is not the same, thus affecting the performance of each transit hub. In terms of delivery trip length, the use of the smart locker is $30.65 \%$ more efficient when compared to parcel delivery service. In order to deliver 222 items, the total trip length for parcel delivery is $717.8 \mathrm{~km}$, while using the smart locker requires a total trip length of $497.83 \mathrm{~km}$.
\end{abstract}

Keywords: efficiency; home delivery service; last mile delivery; smart locker

\section{Introduction}

The last mile delivery is the last trip of an item before it arrives at its final destination ${ }^{4}$. The current increase of last mile delivery is the impact of increasing home delivery service in a region due to the development of ecommerce. The development of e-commerce from year to year has experienced a significant increase. According to Meints (2013), this industry is growing rapidly due to changes in shopping behavior of customers. The results of Boyer's study (2009) show that the use of online buying and selling has increased by over $25 \%$ per year over the past ten years ${ }^{3,20)}$.

In Indonesia, economic growth and the middle class have increased cellphone and internet access which has led to e-commerce growth. As explained by Jokowi (2016) the development of e-commerce has grown rapidly with the number of internet users, reaching 88.1 million. According to Mitra (2014), the transactional value has reached 130 trillion rupiah ${ }^{2}$.

There are several problems of good delivery operation using the home delivery service. These problems include significant order fragmentation, inefficient regulations in an area related to urban goods transportation, limited number of fleets that resulting delivery delays, uncertain time of good receipts, high emissions, security problems, and high shipping costs ${ }^{9,15,21)}$.

One solution to solve the problem of home delivery service is to make use of the smart locker system. The smart locker is a delivery machine in the form of lockers placed in certain locations close to where the customer lives. Smart lockers can be divided into three categories, namely operational lockers, customer lockers, and universal lockers. Currently, a smart locker that can be operated and functions properly is an operational locker. Smart lockers need to be developed to reduce the impact of home delivery service. These effects include the reduction of traffic density, increase cargo usage by consolidating shipments, and shortening of the time taken to handle goods. Currently, smart lockers are spread in 12 major cities in Indonesia, but are not used as best as they could be. This study aims to analyze the operational characteristics of smart lockers, especially in the Jabodetabek area. The study also aims to analyze the efficiency of shipments carried out by this system in comparison to the home delivery service ${ }^{17)}$. 


\section{Literature Review}

E-commerce from year to year has developed significantly. According to Meints (2013), this industry is growing rapidly due to changes in customers' shopping behavior. Boyer's study (2009) shows that the use of online buying and selling has increased by more than $25 \%$ per year over the past ten years ${ }^{3,20)}$. Based on the results of the Internet Standard Magazine research, e-commerce growth in Poland reached $20 \%$ in $2013^{9}$. The results of other studies show that e-commerce has developed between $14 \%$ and $34 \%$ over 10 years since 2010 . This is due to older people beginning to make reservations online. Young people are accustomed to, and will continue to use, bookings online. As a result of the increase of online buying and selling activities, offline stores are decreasing, foodstuffs go to online sales, and the use of smart phones is increasing ${ }^{21)}$.

Four important elements of e-commerce are senders, costumers, governments, and logistics service providers (including operators) ${ }^{21)}$. Huang (2008) said that the quality of logistics service performance is an important component in marketing to build customers' satisfaction, thus an increased number of freight shipments poses a big challenge for logistics service providers ${ }^{6,8}$.

In Indonesia, economic growth and the middle class have increased the use of smart phones and internet connectivity. This has led to increased e-commerce growth. Based on data published by Statista, the value of e-commerce retail sales in 2016 reached 5.65 billion USD, an increase of $23 \%$. PFS estimates that the Indonesian market will be fragmented and become an obstacle in the development of e-commerce in Indonesia ${ }^{22)}$. As explained by Jokowi (2016) the development of ecommerce has developed rapidly with the number of internet users reaching 88.1 million, and according to Mitra (2014) the value of transactions reaches 130 trillion rupiah $^{2)}$. In the next five years, around $73 \%$ of internet users who access via mobile devices will continue to grow. According to e-marketers in 2013, the number of internet users conducting e-commerce was 4.6 million users and total transactions reached 21.9 trillion rupiah. Based on the Economic Census in 2016, e-commerce will grow around $17 \%$ in the last 10 years with a total of 26.2 million businesses ${ }^{1)}$.

As part of logistic system, last mile delivery is the movement of goods from the center of storage or distribution to the final destination. In other words, last mile delivery is the last trip of the goods before arriving to the buyer ${ }^{4,13)}$. Last mile delivery contributes greatly to the flow of transportation and thus can cause certain problems in urban areas. Along with the increased number of last mile deliveries, it impacts on the traffic density of urban transportation. This phenomenon is one of the problems in regions, especially in residential areas ${ }^{5,15,23)}$. Current increase in last mile delivery is the impact of an increase of the home delivery service in a region due to the development of e-commerce. Therefore, last mile delivery has an important role in the sustainability of ecommerce $^{10,11,25)}$. The implementation of good delivery using the home delivery service results in several similar problems throughout the world. Problems include the significant order fragmentation where current users of shipping services not only originate from big cities, but from more rural areas too. As a result, the delivery location is also spread out and regulations related to urban goods transportation are still inefficient ${ }^{9,10,24)}$. Operational problems related to the number of fleets are limited, resulting in delays in delivery ${ }^{9,15,21)}$. The time of the goods receipt is uncertain, and recipients are forced to wait at home. Alternatively, when goods arrive at their destination there are no recipients to receive them ${ }^{15,21,24,25)}$. The vehicles used are small vehicles and their large numbers result in high emissions ${ }^{5,19,20)}$. Those transportation activities contribute to the increase of greenhouse gas concentration in the troposphere ${ }^{12,16)}$. There are also security problems because at times, goods arrive damaged ${ }^{15,20)}$. Finally, there are high shipping costs $^{6,15,21)}$.

One solution to solve the home delivery service problem is to implement a smart locker system. The smart locker is a delivery machine in the form of lockers placed in certain locations close to where the customer lives. Smart lockers can be divided into three categories, namely operational lockers, customer lockers, and universal lockers. Currently, a smart locker that can be operated and functions properly is an operational locker. Smart lockers need to be developed to reduce the impact of home delivery service. These effects include the reduction of traffic density, increase cargo usage by consolidating shipments, and shortening of the time taken to handle goods. Currently, smart lockers are spread in 12 major cities in Indonesia but are not used as best as they could be. This study aims to analyze the operational characteristics of smart lockers, especially in the Jabodetabek area. The study also aims to analyze the efficiency of shipments carried out by this system in comparison to the home delivery service ${ }^{9}$. In Indonesia, the use of smart lockers began to develop in 2017. The company that became a pioneer of this was Paxel. Since 2017, there have been 107 lockers in 12 major cities in Indonesia consisting of 71 operational lockers and 38 customer lockers. Currently all smart lockers have not been activated. The lockers that have been activated are currently in the transit hub of each city and there are two smart lockers outside the transit hub, hereinafter referred to as the locker point ${ }^{17)}$.

At present, there are four types of dimensions used in the service; small, medium, large, and custom size for the goods. The maximum allowable weight for one item is 5 $\mathrm{kg}$. There are eleven slots placed in one locker, where the total volume for each slot is $100.00 \mathrm{~cm}^{3}$. The maximum allowable weight is around $200 \mathrm{~kg}$.

There are several differences of shipping flows in the shipment process when compared to the parcel delivery 
service. The shipping flow using the direct delivery service starting from the producer warehouse and ending with the customer is illustrated in Fig. 1.

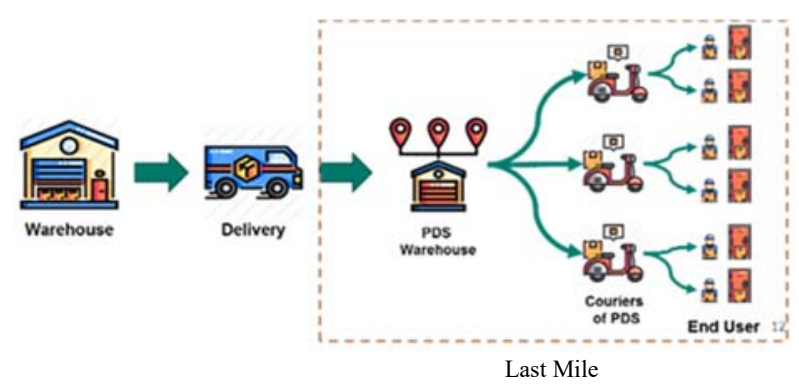

Fig. 1: Trip chain direct delivery service

Based on Fig. 1, the delivery of goods starts from the producer warehouse to the home delivery service warehouse using truck delivery. In the home delivery service warehouse, the items are regrouped according to the shipping area. The items that have been grouped are then sent by the courier to the customer's address and the trip is called the last mile delivery.

Delivery when the destination is a smart locker is different in the last mile delivery stage. The flow of goods from the producer warehouse to the end customer is illustrated in Fig. 2

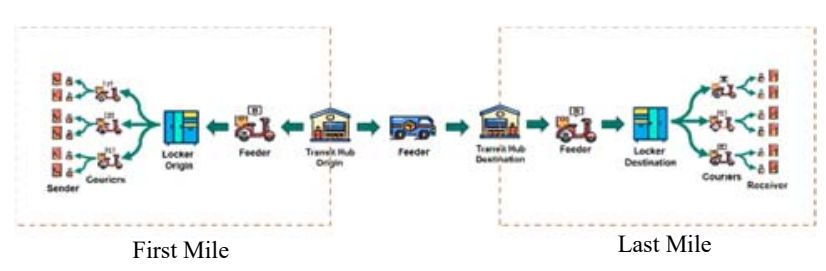

Fig. 2: Trip chain smart locker

Based on Fig. 2, the delivery of goods starts when the courier picks up an item at the sender's location and the item is placed in the nearest locker. Furthermore, the feeders take goods from the locker to be sent to the origin transit hub. Goods in the origin transit hub will be carried out by another feeder and sent to the destination transit hub. Then items already in the destination transit hub are sent to the destination locker using a feeder. The item is delivered directly by the courier to the customer and the trip is called the last mile delivery.

\section{Methodology}

The research variables are waiting time, travel length in one round trip and per item, travel time in the pickup and delivery process, as well as the travel length of parcel delivery service provider. The basic data related to these variables is obtained from the travel diary of couriers of the Smart Locker service providers. The data collection was carried out for one week with a total of 12 transit hubs spread in the Jabodetabek area.

Travel length calculation was carried out using Google
Maps based on data related to the pick-up and delivery address. The average waiting time, as well as the travel length and time needed to deliver one item, is obtained through a record in the travel diary. There are two tools that are used to describe the operational characteristics of the smart locker system: Descriptive statistical method and Manova tests. Descriptive statistical method is a method that relies on the collection and presentation of data in order to obtain an outcome which describes the condition of the data. On the other hand, Manova tests (Multivariate Analysis of Variance) with SPSS software is one of the statistical tests for Anova test that has more than one dependent variable, or known as the multivariate form ${ }^{7,14)}$. The efficiency of the smart locker compared to the direct delivery service was analyzed using secondary data generated from Ramadhan's study (2018) on the total length of trips carried out by the direct delivery service used to deliver goods.

\section{Result and Discussion}

\subsection{Smart Locker Characteristics}

The data used as the independent variable is the location of the transit hub. The data used as the dependent variable is data in the Pickup and Delivery process.

Based on the Manova test on the waiting time variable (i.e. courier's waiting time) at the customer's location in the pickup and delivery process, there are differences in customer characteristics between each transit hub. According to Fig. 3 and Fig. 4, it can be observed that the normal sample distribution and the required time for the

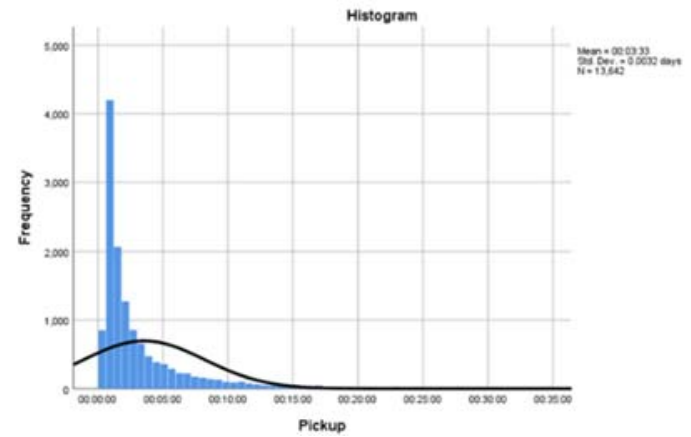

waiting time process is in the range of $0-4$ minutes with a percentage up to $75.79 \%$ in the pickup process and $89.6 \%$ in the delivery process.

Fig. 3: Frequency distribution graph for waiting time in pickup process

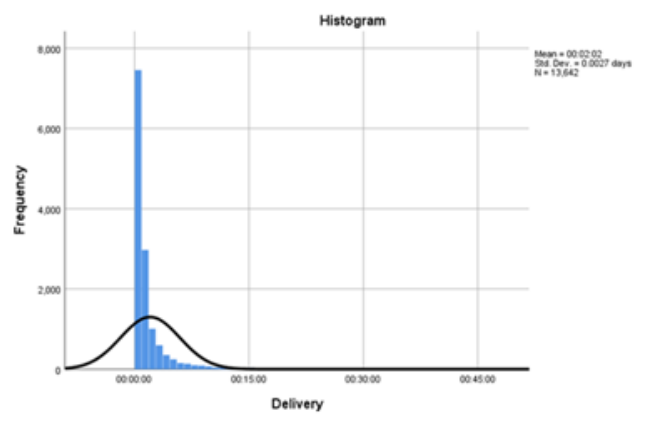


Fig. 4: Frequency distribution graph for waiting time in delivery process

Table 1. Calculation result of mean and standard deviation for waiting time

\begin{tabular}{|c|c|c|}
\hline & $\begin{array}{c}\text { Mean } \\
\text { (minutes) }\end{array}$ & $\begin{array}{c}\text { Standard Deviation } \\
\text { (minutes) }\end{array}$ \\
\hline Pickup & $0: 03: 33$ & $0: 04: 39$ \\
\hline Delivery & $0: 02: 02$ & $0: 03: 52$ \\
\hline
\end{tabular}

According to Table 1 , the average value of waiting time in pickup process is 3 minutes 33 seconds with a standard deviation of 4 minutes 39 seconds, while the delivery process is 2 minutes 2 seconds with a standard deviation of 3 minutes 52 seconds. Some deliveries require a waiting time over 10 minutes. An interview with service providers claimed that this occurred due to several things, including items not ready for pick up, as well as customer who are not at the location of the pickup. Information about this waiting time variable is needed considering that one component contributing to the length of the round trip from the shipping courier is the waiting time. If the waiting time can be shortened, the travel efficiency will also be improved.

Based on the travel length in one round trip variable, there are differences in performance between each transit hub in both the pickup and delivery process. According to Fig. 5 and Fig. 6, it can be observed that the normal sample distribution and the travel length in one round trip is in the range of $10-30 \mathrm{~km}$.

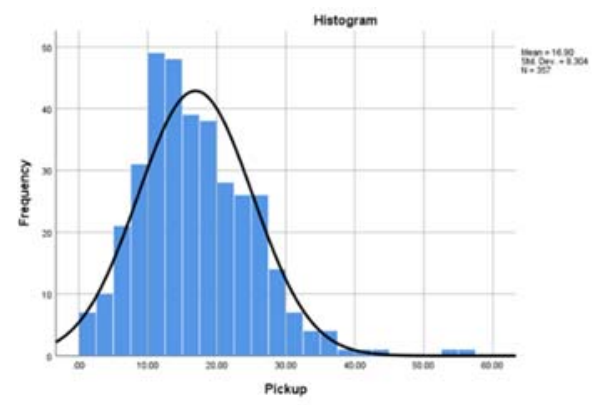

Fig. 5: Frequency distribution graph for the travel length in one round trip in pickup process

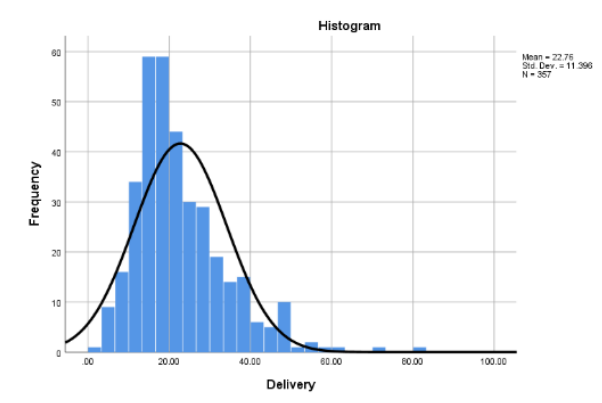

Fig. 6: Frequency distribution graph for the travel length in one round trip in delivery process
Table 2. Calculation result of mean and standard deviation for the travel length in one round trip

\begin{tabular}{|c|c|c|}
\hline & Mean & Standard Deviation \\
\hline Pickup & $16.90 \mathrm{Km}$ & $8.3 \mathrm{Km}$ \\
\hline Delivery & $22.76 \mathrm{Km}$ & $11.40 \mathrm{Km}$ \\
\hline
\end{tabular}

According to Table 2, the average travel length in one round trip in the pickup process at $16.9 \mathrm{~km}$ with a standard deviation of $8.3 \mathrm{~km}$. In delivery process, the average travel length is $22.76 \mathrm{~km}$ with a standard deviation of $11.4 \mathrm{~km}$. The difference is due to several transit hubs that have a wider coverage area compared to other transit hubs. In addition, this can occur because the system used at this time sometimes makes mistakes in detecting a destination transit hub that has the closest location to the destination address, where the chosen destination transit hub sometimes has a farther length than it should be. Data related to the travel length can be used to optimize delivery assignments. Optimal shipping assignments are the result of a trade-off between customer satisfaction and operating costs of shipping service providers. The higher the travel length in one round trip, the longer the arrival time of the courier at the customer's location. The effect of this is reduced customer satisfaction. On the contrary, if the round-trip length is reduced, transit hub and human resources facilities are needed to reduce coverage. This will increase the operational costs of service providers, even though on the other hand the customer will be satisfied. Operational errors such as errors in detecting the destination of the transit hub can be solved efficiently by adjusting the length of the round trip to increase efficiency.

Based on the travel length per item of goods sent, there are also differences in characteristics between each transit hub, both in the pickup and delivery process. According to Fig. 7 and Fig. 8, it can be observed that the normal sample distribution and the travel length per item is in the range of $5-7,5 \mathrm{~km}$.

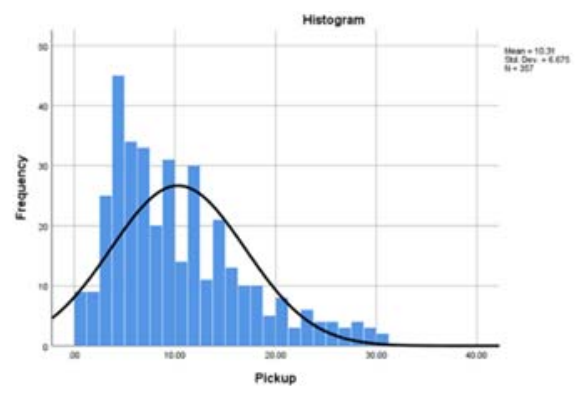

Fig. 7: Frequency distribution graph for the travel length per item in pickup process 


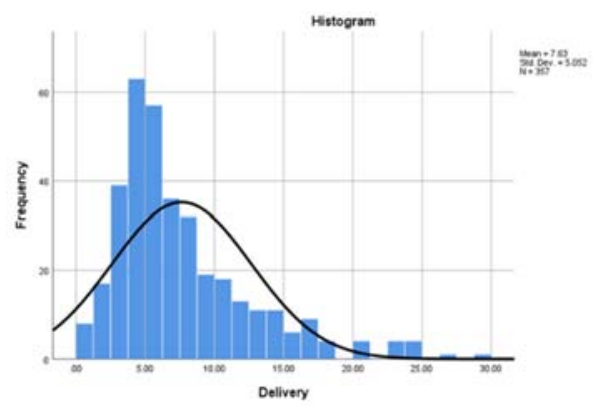

Fig. 8: Frequency distribution graph for the travel length per item in delivery process

Table 3. Calculation result of mean and standard deviation for the travel length per item

\begin{tabular}{|c|c|c|}
\hline & Mean & Standard Deviation \\
\hline Pickup & $10.31 \mathrm{Km}$ & $6.67 \mathrm{Km}$ \\
\hline Delivery & $7.63 \mathrm{Km}$ & $5.05 \mathrm{Km}$ \\
\hline
\end{tabular}

According to Table 3, the average value of travel length per item in the pickup process is $10.31 \mathrm{~km}$ with a standard deviation of $6.67 \mathrm{~km}$, while in delivery process this is 7.63 $\mathrm{km}$ with a standard deviation of $5.05 \mathrm{~km}$. The travel length per item variable is a derivative of the length in a round trip. The total average of the round trip length in the pickup process $(16.9 \mathrm{~km})$ is shorter than the delivery process $(22.76 \mathrm{~km})$, but when viewed on a per-item basis, the pickup process is longer $(10.31 \mathrm{~km} /$ item $)$ than the delivery process $(7.63 \mathrm{~km} /$ item $)$. This shows that the delivery process is more productive than the pickup process. This might occur because the customer is still unfamiliar with the pickup service, having only previously used delivery services.

Based on the travel speed variable, there are differences in performance between the transit hub in the pickup process, while in the delivery process there is no significant difference in performance. According to Fig. 9 and Fig. 10, it can be observed that the normal sample distribution and travel speed is in the range of $20-60$ $\mathrm{km} / \mathrm{h}$.

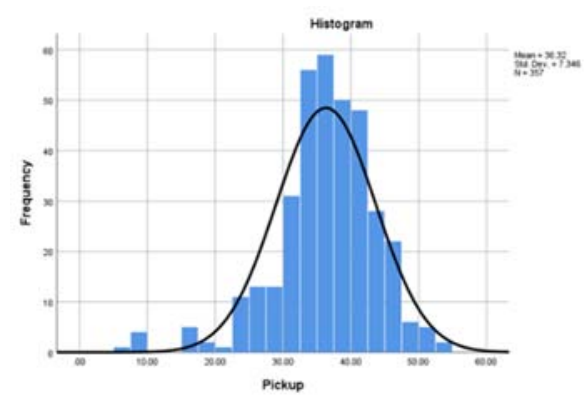

Fig. 9: Frequency distribution graph for travel speed in pickup process

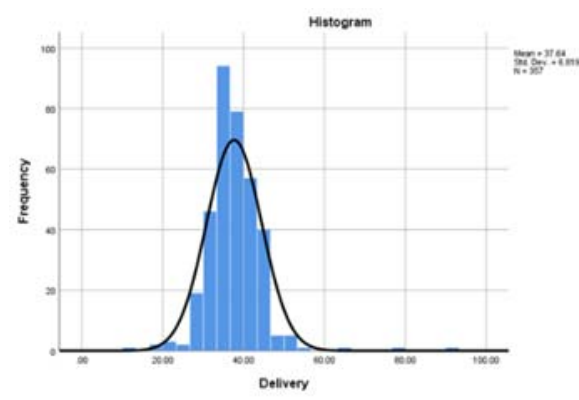

Fig. 10: Frequency distribution graph for travel speed in delivery process

Table 4. Calculation result of mean and standard deviation for travel speed

\begin{tabular}{|c|c|c|}
\hline & Mean & Standard Deviation \\
\hline Pickup & $36.32 \mathrm{~km} / \mathrm{hr}$ & $7.35 \mathrm{~km} / \mathrm{hr}$ \\
\hline Delivery & $37,64 \mathrm{~km} / \mathrm{hr}$ & $6.82 \mathrm{~km} / \mathrm{hr}$ \\
\hline
\end{tabular}

According to Table 4, the average travel speed in the pickup process is $36.32 \mathrm{~km} / \mathrm{hr}$ with a standard deviation of $7.35 \mathrm{~km} / \mathrm{hr}$, while in the delivery process this is 37.64 $\mathrm{km} / \mathrm{hr}$ with a standard deviation of $6.82 \mathrm{~km} / \mathrm{hr}$. The travel speed is much affected by traffic conditions in the area around the transit hub. However, service providers should be able to deal with situations that are influenced by external factors due to the fact that travel speed is closely correlated with the delivery productivity per day by regulating delivery times that pay more attention to traffic congestion fluctuations.

\subsection{Comparison of Smart Locker and Direct Delivery Service}

Ramadhan (2018) on "Comparative Analysis of the Impact of Carbon Emissions from Last Mile Delivery Activities of Online and Conventional Expenditures" illustrated the total travel length carried out by direct delivery service to deliver 222 pieces of goods. The study recorded the average number of items in one round trip and the average length of the shipping route. This study also showed the average number of items in one round trip and the average length of the shipping route. After the two sets of data are obtained, the calculation was done to obtain the number of round trips and the total travel length ${ }^{18)}$. The results are showed in Table 5. 
Table 5. Comparison between smart locker and direct delivery service

\begin{tabular}{|c|c|c|}
\hline Variable & $\begin{array}{c}\text { Direct Delivery } \\
\text { Service }\end{array}$ & Smart Locker \\
\hline Number of Items & 222 & 222 \\
\hline $\begin{array}{c}\text { Average of } \\
\text { Addresses in one } \\
\text { round trip }\end{array}$ & 13 & 4 \\
\hline $\begin{array}{c}\text { Average of travel } \\
\text { length per item } \\
(\mathrm{km})\end{array}$ & 42.03 & 8.97 \\
\hline $\begin{array}{c}\text { Total round trip } \\
\text { for 222 items }\end{array}$ & 18 & 56 \\
\hline $\begin{array}{c}\text { Total of travel } \\
\text { length (km) }\end{array}$ & 717.80 & 497.83 \\
\hline
\end{tabular}

The table above showed that the smart locker system is more efficient than the direct delivery service. In the direct delivery service, the average number of addresses in one round trip is 13 items with an average travel length of $42.03 \mathrm{~km}$. Therefore, to deliver 222 items, 18 round trips are required with a total travel length of $717.80 \mathrm{~km}$ (Ramadan, 2018). In the smart locker system, the average number of addresses in one round trip is four with an average travel length of $8.97 \mathrm{~km}$, and therefore to deliver 222 items, 56 round trips are required with a total travel length of $497.83 \mathrm{~km}$. Therefore, the efficiency using a smart locker is at $30.65 \%$ in relation to total travel length. In terms of round trips needed, the number of round trips needed in the smart locker system is higher than in the direct delivery service. This could be due to slot times in the smart locker system. A slot time is the time determined by the smart locker service provider for pickup and delivery processes. There are eight slot times used from 08:00 to 22:00 with a difference of two hours for one slot time. Thus, the items carried for one round trip are only at a low figure because they adjust to the slot time used.

\section{Conclusion}

Based on the results of this study, it can be concluded that the performance for each transit hub in the pickup and delivery process differs significantly due to variances of the waiting time and travel length variables. In the waiting time variable, this difference could be because items are not ready to be picked up or that customers are not at the location of the pickup. In the travel length variable, the difference is caused by several transit hubs that have a wider coverage area compared to other transit hubs and the system used sometimes makes errors in detecting a nearest transit hub. Thus, the selected transit hub is sometimes further away than it should be. The results of the analysis of the operational characteristics of the smart locker could be used to improve the customer service level, as well reducing operational costs through efforts of improvement related to the variables of this study.

A comparison between the smart locker and direct delivery service showed that the use of smart lockers is more efficient in terms of the total travel length compared to the direct delivery service. To deliver 222 items using the direct delivery service, a total travel length of 717.8 $\mathrm{km}$ is required, while the smart locker requires a total travel length of $497.83 \mathrm{~km}$. Therefore, the efficiency obtained in smart locker usage is $30.65 \%$.

\section{Acknowledgements}

This research is supported by research funds made available through the Research Fund of PITTA (Publikasi Terindeks Internasional Untuk Tugas Akhir Mahasiswa UI) of Universitas Indonesia, 2019.

\section{References}

1) Berinovasi. (2017, December 11). Perkembangan ECommerce di Indonesia. Accessed September 12, 2018, from Berinovasi.com: http://berinovasi.com/2017/12/11/perkembangan-ecommerce-di-indonesia/

2) Binus University. (2016, October 24). E-Commerce di Indonesia dan Perkembangannya. Accessed September 12, 2018, dari Binus University: https://sis.binus.ac.id/2016/10/24/e-commerce-diindonesia-dan-perkembangannya/

3) Boyer, K. K., Prud'homme, A. M., \& Chung, W, The last mile challenge: evaluating the effects of customer density and delivery window (2009), pp 185-199.

4) Datexcorp. (n.date). What is Last Mile Delivery? Part 1: How Omnichannel Retail is Affecting Transportation \& Logistics. Accessed September 12, 2018, dari Datexcorp: https://www.datexcorp.com/last-mile-delivery-part1-omni-channel-retail-affecting-transportationlogistics/

5) Gevaers, R., Van de Voorde, E., \& Vanelslander, T., Cost modelling and simulation of last-mile characteristics in an innovative B2C supply chain environment with implications on urban areas and cities, (2014), pp 398-411.

6) Ghajargar, M., Zenezini, G., \& Montanaro, T, Home Delivery Service: Innovation and Emerging Needs, (Elsevier, Italy, 2016), pp 1371-1376.

7) Harinaldi, Prinsip-prinsip Statistik untuk Teknik dan Sains, (Erlangga, Jakarta, 2005)

8) Huang, Y., \& Kuo, Y, The evaluation of logistics service quality on home delivery service for online auction (2008, October 12-15), pp 1343-1348.

9) Iwan, S., Kijewska, K., \& Lemke, J, Analysis of Parcel Lockers Efficiency as the Last Mile Delivery Solution: The result of the research in Poland, (Elsevier, Poland, 2015)

10) Janjevic, M., Winkenbach, M., \& Merchan, D., Integrating collection-and-delivery points in the strategic design of urban last-mile e-commerce 
distribution networks, (Elsevier, United States, 2019), pp 37-67.

11) Lemke, J., Iwan, S., \& Korczak, J, Usability of the Parcel Lockers from the Customer Perspective: The Research in Polish Cities, (Elsevier, Poland, 2016).

12) Lestari, N. A., Reduction of $\mathrm{CO} 2$ Emission by Integrated Biomass Gasification-Solid Oxide Fuel Cell Combined with Heat Recovery and in-situ CO2 Utilization, (Evergreen, Japan, 2019), pp 254-261.

13) Lindner, J, Last Mile Logistics Capability: a Multidimensional System Analysis for a General Modelling and Evaluation Approach, (Dipl. Technical University of Munich, German, 2011)

14) Martono, N., Metode Penelitian Kuantitatif, (Rajawali Pers, Jakarta, 2012)

15) Morganti, E., Seidel, S., Blanquart, C., \& Laetitia, The impact of e-commerce on final deliveries: alternative parcel delivery services in France and Germany, (Elsevier, Germany, 2014).

16) Pal, A., Uddin, K., Thu, K., \& Saha, B. B., Environmental Assessment and Characteristics of Next Generation Refrigerants, (Evergreen, Japan, 2018), pp 58-66.

17) PT PaxelBox Digital Unggul (Paxel). (2019). Paxlock Lockers. Jakarta.

18) Ramadhan, S. G. (2018). Analisis Komparatif Dampak Emisi Karbon dari Aktivitas Last Mile Delivery Belanja Online dan Konvensional.

19) Turner, K. M., \& Nagel, K., How Driving Multiple Tours Affects the Results of Last Mile Delivery Vehicle Routing Problems, (Elsevier, Germany, 2019), pp 840-845.

20) van Duin, J., de Goffau, W., Wiegmans, B., Tavasszy, L., \& Saes, M, Improving Home Delivery Efficiency by Using Principles of Address Intelligence for B2C Deliveries, (Elsevier, Netherland, 2015)

21) Visse, J., Nemoto, T., \& Browne, M, Home Delivery and the Impacts on Urban Freight Transport: A Review, (Elsevier, Italy, 2014)

22) Wardhani, S. (2017, September 12). Perkembangan E-commerce di Indonesia (1). Accessed September 12, 2018, from Validnews.co: https://www.validnews.id/Perkembangan-Ecommerce-di-Indonesia--1--YXAiJ

23) Yuen, K. F., Wang, X., Wendy Ng, L.T., \& Wong, Y. D., An Investigation of customers' intention to use self-collection services for last-mile delivery, (Elsevier, Singapore, 2018), pp 1-8.

24) Zhang, Y., un, L., Hu, X., \& Zhao, C., Order consolidation for the last-mile split delivery in online retailing, (Elsevier, China, 2019).

25) Zhou, M., Zhao, L., Campy, K. S., et al, Understanding consumers' behavior to adopt selfservice parcel services for last-mile delivery. (Elsevier, China, 2019). 